Höfig, D., et al., 2021, Annually resolved sediments in the classic Clarkia lacustrine deposits (Idaho, USA) during the middle Miocene Climate Optimum: Geology, v. 49, https://doi.org/10.1130/G48901.1

\title{
Annually-resolved sediments in the classic Clarkia lacustrine deposits (Idaho, USA) during the middle Miocene Climate Optimum
}

Daianne Höfig ${ }^{1}$, Yi Ge Zhang ${ }^{1}$, Liviu Giosan ${ }^{2}$, Qin Leng ${ }^{3}$, Jiaqi Liang ${ }^{3}$, Mengxiao Wu ${ }^{3}$, Brent Miller $^{4}$, Hong Yang ${ }^{3}$

${ }^{1}$ Department of Oceanography, Texas A\&M University, College Station, Texas, 77843, USA

${ }^{2}$ Woods Hole Oceanographic Institution, Woods Hole, 02543, Massachusetts, USA

${ }^{3}$ Laboratory for Terrestrial Environments, College of Arts and Sciences, Bryant University, Smithfield, 02917, Rhode Island, USA

${ }^{4}$ Department of Geology and Geophysics, Texas A\&M University, College Station, Texas 77843, USA

\section{This Supplemental Material contains}

- Supplemental Tables (separate MS Excel files)

Table S1 - U-Pb zircon data (LA-ICP-MS and TIMS-ID) from the ashfall layers of the Clarkia paleolake deposit (Site P-33).

Table S2 - Micro X-ray fluorescence elemental ratios and color intensity from the varved-sediments (units 2B, 2D, and 5A) of the Clarkia paleolake deposit (Site P-33).

- Methods

Zircon U-Pb Geochronology

Micro X-Ray Fluorescence

- Supplemental Figures

Figure S1 - Concordia diagrams

Figure S2 - Selected images of zircon grains found in the ash layers of Site P-33.

Figure S3 - Selected microphotographs of textural and mineralogical features found in the units of Site P-33.

Figure S4 - Spectral analysis of the Unit 2D of Site P-33.

Figure S5 - Spectral analysis of the Unit 5A of Site P-33.

\section{- References cited}




\section{METHODS}

\section{Zircon U-Pb Geochronology}

Volcanic ash samples collected from Clarkia Site P-33 were independently analyzed in three geochronology laboratories. Samples were analyzed via LA-ICP-MS in the Arizona LaserChron Center at the University of Arizona, using a Photon Machines Analyte G2 excimer laser equipped with HelEx ablation and plasma source of an Element2 HR ICPM. Imaging was carried out using a Hitachi 3400N scanning electron microscope and a Gatan CL2 detector system. Methods are as described by Gehrels et al. (2008). At Texas A\&M University, the volcanic samples were analyzed in a Thermo Scientific ${ }^{\mathrm{TM}}$ iCAP RQ $^{\mathrm{TM}}$ quadrupole mass spectrometer for LA-ICP-MS and Triton for CA-ID-TIMS at its R. Ken Williams '45 Radiogenic Isotope Geosciences Laboratory. LA-ICP-MS procedures are as detailed in Barr et al. (2019) and Yancey et al. (2018); CA-ID-TIMS procedures are described in Miller et al. (2018) and Park et al. (2014), except this study used the EarthTime 205Pb-233U-235U spike (Condon et al., 2015). CA-ID-TIMS data were reduced using the "YourLab" algorithms of Schmitz and Schoene (2007). Final $\mathrm{U}-\mathrm{Pb}$ age interpretations are given in the form $\mathrm{AGE} \pm \mathrm{X} / \mathrm{Y} / \mathrm{Z}$, where $\mathrm{AGE}$ is the preferred age interpretation as described in the text and $\mathrm{X}, \mathrm{Y}, \mathrm{Z}$ represent the uncertainty taking into account random and systematic analytical sources $(\mathrm{X})$, those combined with contributions from uncertainty in the ET535 spike (Y) and both of those and including decay constant uncertainties (Z). Corrections for ${ }^{230} \mathrm{Th}$ were performed assuming a magmatic $\mathrm{Th} / \mathrm{U}$ ratio of 3.0. At the China University of Geosciences at Wuhan, the LA-ICP-MS system consists of an Agilent7500a with a 193nm ArF-excimer laser.

Approximately $10 \mathrm{~kg}$ of each ash layer was collected, hand-crushed, washed, and sonicated multiple times to disaggregate clusters of glass shards and clay minerals as described by Smith et al. (2018). These concentrates were separated by density (hand-panning and Wifely table), magnetism (Frantz Isodynamic Magnetic Separator), and gravity (Methylene Iodine). Zircon residue was selected based on their morphology, size, color, as well as the absence of fractures, overgrowth, and inherited nuclei. For LA-ICP-MS, a dozen individual zircon grains were mounted in an epoxy stand with primary standards (NIST 612 glass and 91500 zircon), which was polished to remove surface layers affected by lead loss. For Unit 2C, 110 spots were obtained from 85 grains, yielding 85 concordant detrital ages; for Unit 4, 75 spots and grains yielded 56 concordant detrital ages (20 analyses define Miocene volcanogenic population); and for Unit 5B, 48 measurement spots out of a total of 108 on 73 grains yielded concordant ages (23 analyses define Miocene volcanogenic population). For the ID-TIMS, the selected Miocene zircon grains previously analyzed by LA-ICP-MS were dissolved in a Teflon beaker following Mattinson (2005). Age calculation was performed following Wiedenbeck et al. (1995) and Concordia diagrams were obtained using Isoplot v. 247 (Ludwig, 2003). 


\section{Micro X-Ray Fluorescence $(\mu-X R F)$}

Sample blocks measuring 5-9:4:2 cm (L:W:H) from the laminated units 2B, 2D, and 5A from Site P-33 were analyzed at a step size of $5 \mathrm{~mm}$ in the XRF Core Scanning Facility of the IODP Gulf Coast Repository using a third-generation Avaatech XRF Core Scanner. The 27 chemical elements obtained were arranged into 702 ratio combinations, of which few ratios were shortlisted based on their reciprocity with the varve-structures and representativeness of grainsize change. To increase the resolution of the data, $\mu$-XRF was employed on the same samples using the Cox Analytical's ITRAX XRF micro-scanner at the Woods Hole Oceanographic Institution. Elemental counts were recorded at 200-micrometer intervals using a Mo X-Ray tube set to $30 \mathrm{kV}$ and $50 \mathrm{~mA}$ with $10 \mathrm{~s}$ scanning time. The XRF spectra were interpreted and the peak areas were quantified using software Q-Spec. This approach enabled data acquisition from the sub-mm varve layers of Clarkia deposit. Analytical settings follow Croudace et al. (2006).

Sedimentation rates were statistically estimated employing spectral analysis in the selected elemental ratios, using the Acycle 2.0 package for MATLAB (Li et al., 2019). Firstly, the dataset was filtered to remove data points affected by heterogeneities in the sample surface, such as fractures. For this procedure, argon counts and photographs were used to determine problematic areas of the sample. Then, the data set was detrended using a robust quadratic regression (rloess). Next, the time series interpretation detected cycles across the stratigraphic sample length using periodograms that show the most dominant signals (above 95\% confidence interval) standing out from the background noise (Mann \& Lees, 1996). Further signal processing employed evolutionary power spectra (Fast Fourier Transform) that addressed the autocorrelation of the dataset and its cyclicity (Muller \& MacDonald, 2000). The data was filtered using a bandpass, assuming Gaussian distribution, to isolate the frequency representing the most preeminent cycle (Muller \& MacDonald, 2000). In addition to the XRF data acquisition, a semi-automatic image-analysis MATLAB script was used in scanned images from the samples to detect the change of the colors in the varved sediments (Trauth, 2015). Spectral analysis of the obtained color intensity transects followed the same steps as described for the $\mu-$ XRF data.

Varves are commonly preserved in modern temperate and high latitudinal lake deposits (Zolitschka et al., 2015) and found throughout the geological record, such as the Eocene Green River Formation (Utah, USA; Anderson \& Dean, 1988). Long-term geomorphologic stability under seasonal climate provides favorable conditions for preserving varved structures at Clarkia (Zolitschka et al., 2015). The calculation of varve-years in the age model for the Site P-33 were solely based on grain-size variation ratios $(\mathrm{K} / \mathrm{Ti}$ and $\mathrm{Rb} / \mathrm{Zr}$ ) because as the lakes shallowed, forming a Konzentrat-Lagerstätte, there was a detachment between fossil preservation (color* and $\mathrm{Inc} / \mathrm{Coh}$ ) and the varve formation. 


\section{SUPPLEMENTAL FIGURES}
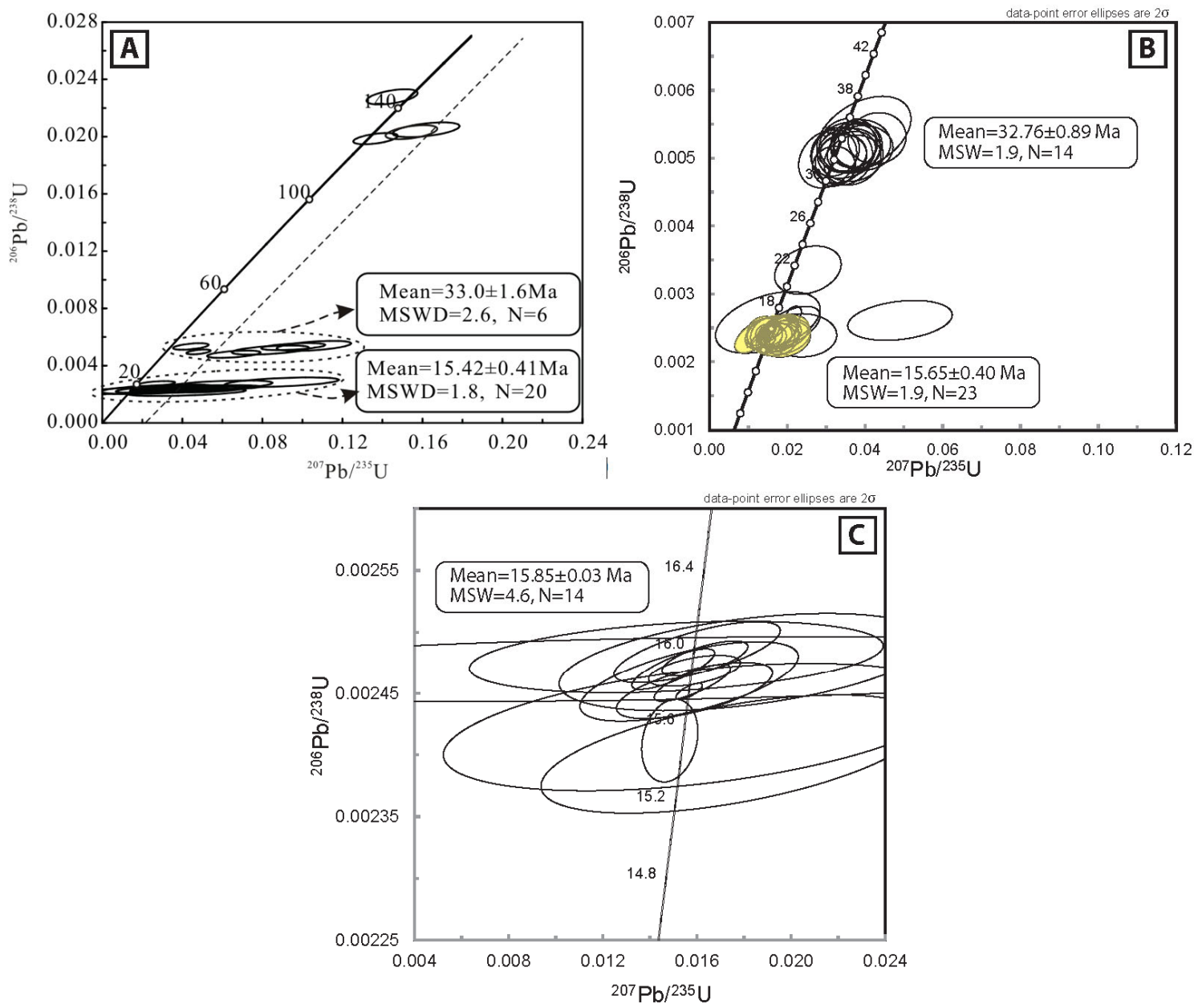

Figure S1. Concordia diagrams of the volcanic ash layers units 4 and 5B. A) LA-ICP-MS analysis of Unit 4 sample (at China University of Geosciences at Wuhan). Two populations are found, in which the zircon grains yielded weighted mean ${ }^{206} \mathrm{~Pb} /{ }^{238} \mathrm{U}$ of $33.0 \pm 1.6$ and $15.42 \pm 0.41 \mathrm{Ma}$ (MSWD = 2.6 and 1.8, respectively). B) LA-ICP-MS analysis of Unit 5B sample (at Texas A\&M University). Two populations of zircon grains yielded weighted mean ${ }^{206} \mathrm{~Pb} /{ }^{238} \mathrm{U}$ of $32.76 \pm 0.89$ and $15.65 \pm 0.40 \mathrm{Ma}(\mathrm{MSWD}=1.9)$. The highlighted subset of zircon grains was later analyzed via ID-TIMS. C) ID-TIMS analysis of the Miocene population from the Unit 5B sample $(15.85 \pm 0.03 \mathrm{Ma}$; MSWD $=4.6)$ previously analyzed by LA-ICP-MS (at Texas A\&M University). The weighted mean ${ }^{206} \mathrm{~Pb} /{ }^{238} \mathrm{U}$ is $15.78 \pm 0.035 / 0.035 / 0.039$ (uncertainties listed in order of analytical / including tracer / including decay constants). All zircon analyses from sample $2 \mathrm{C}$ are significantly older than the depositional age (Table DR1) and are interpreted to be either detrital or xenocrystic grains. 

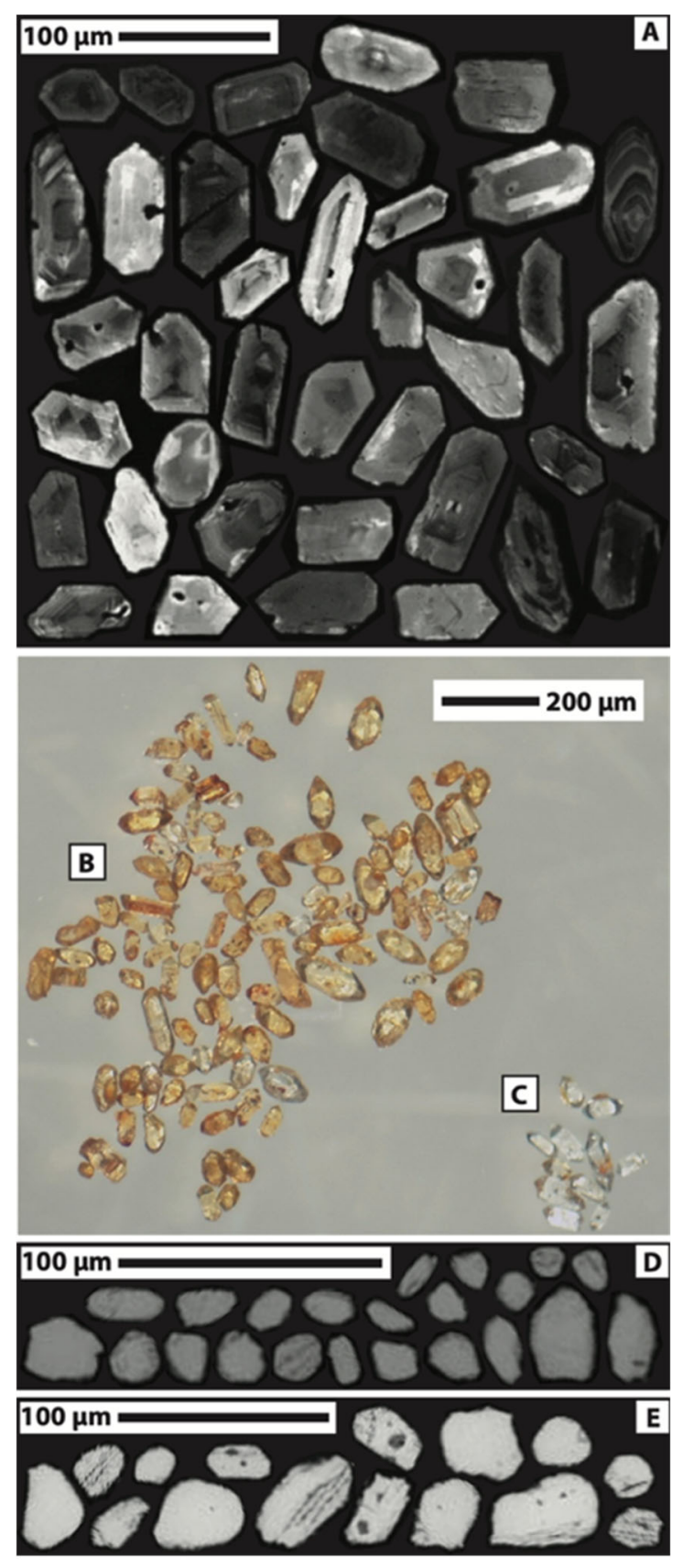

Figure S2. Selected images of zircon grains found in the ash layers of Site P-33. A) Cathodoluminescence images of Miocene and Oligocene zircon grains of Unit 4 sample (dated via LA-ICP-MS; China University of Geosciences at Wuhan). B) Oligocene zircon population of Unit 5B (dated via LA-ICP-MS; Texas A\&M University). C) Miocene zircon population of Unit 5B (dated via LA-ICP-MS and ID-TIMS; Texas A\&M University). D) Detrital zircon grains of Unit 2C (dated via LA-ICP-MS; University of Arizona). E) Detrital zircon grains of Unit 4 (dated via LA-ICP-MS; University of Arizona). 

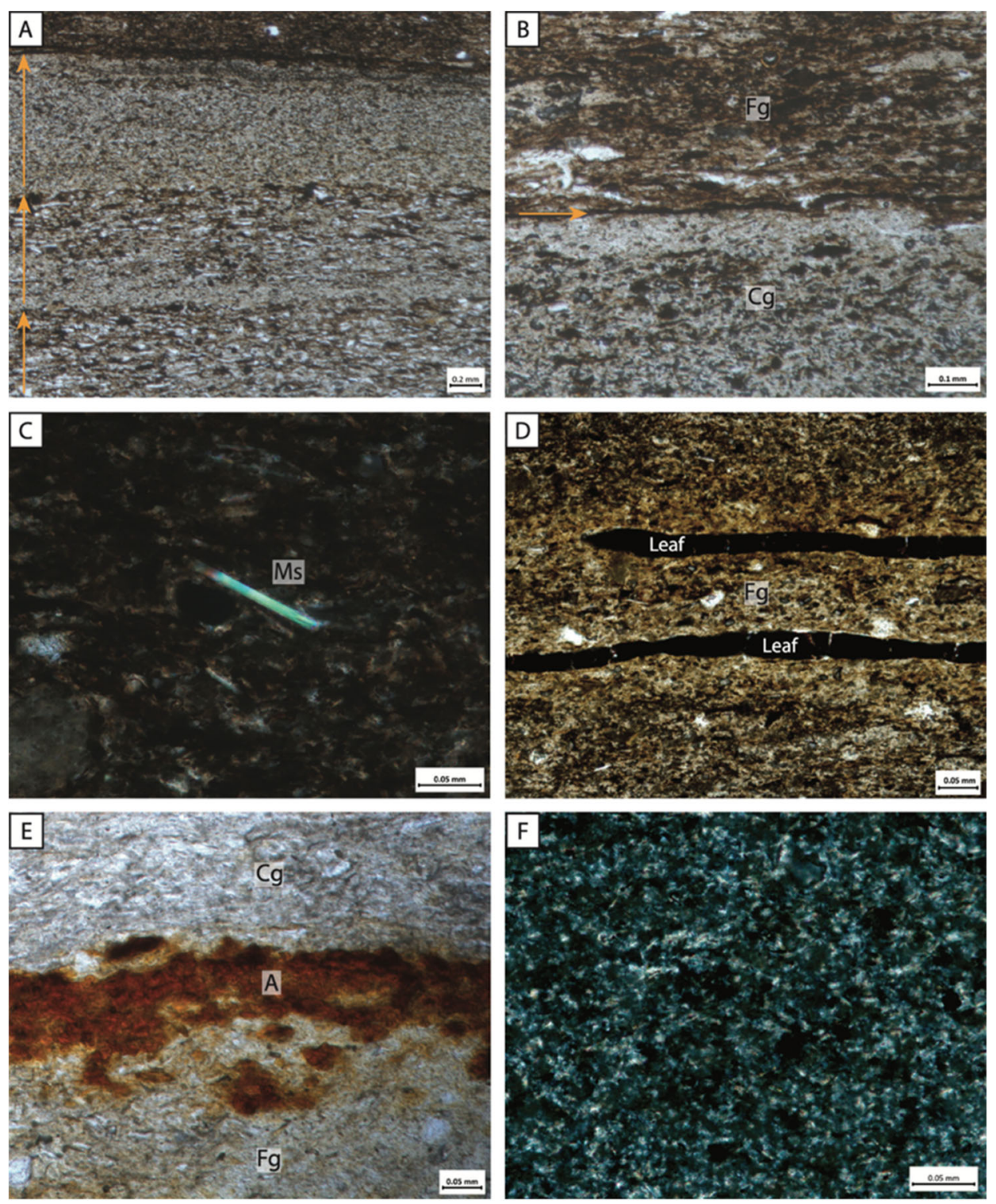

Figure S3. Selected microphotographs of textural and mineralogical features found in the units of Site P-33. A) Varve couplets formed by finning-up cycles, which are represented by arrows in the image (plane-polarized light [PPL]). B) Contact between the dark, fine-grained layer (Fg) and light, coarse-grained layer $(\mathrm{Cg})$. These layers vary in grain-size and proportions of detrital quartz, mica, opaque minerals, epidote, zircon, and apatite (PPL). C) Detrital muscovite (Ms) grain is a common occurrence in the varved-sediments of the unoxidized zone (cross-polarized light [XPL]). D) Fossil leaves (Leaf) distributed in the dark, fine-grained layer (Fg) (PPL). E) Iron-alteration product (A) percolating the contact between the dark, fine-grained layer (Fg) and light, coarse-grained layer $(\mathrm{Cg})$ in the Unit 5A. This unit contains quartz, mica, and opaque minerals percolated with iron alteration products._(PPL). F) At Site P-33 the ashfall layers present ultra-fine-grain size. The matrix is formed by glass shards, quartz, and muscovite and rare accessory phases (cross-polarized light [XPL]). 


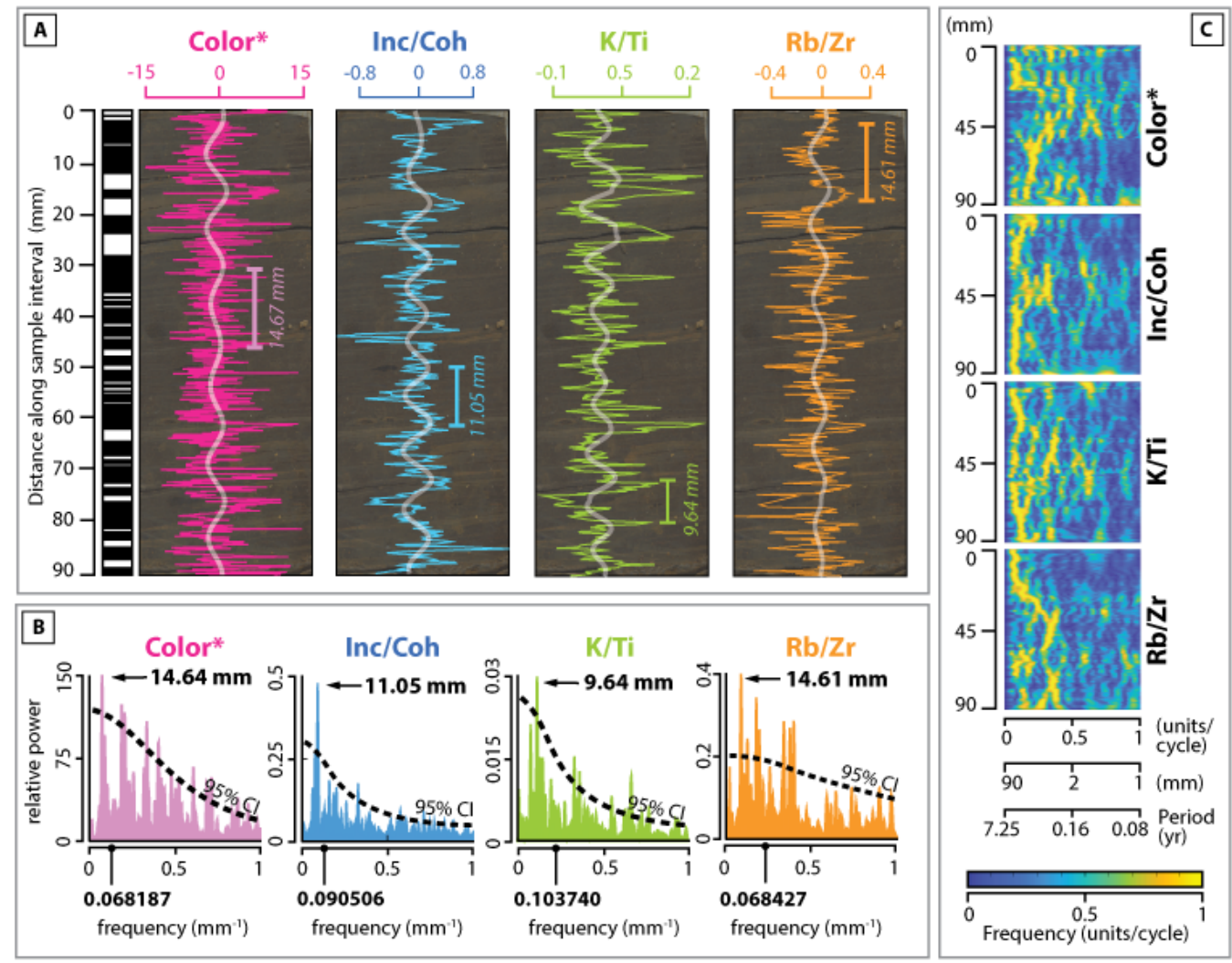

Figure S4. Spectral analysis of Unit 2D. (A) Frequency analysis of Color*, Inc/Coh, K/Ti and $\mathrm{Zr} / \mathrm{Rb}$ ratios show depositional cycles at every $9.64-14.64 \mathrm{~mm}$ in Unit 2D. All data are detrended and filtered using bandpass. Bars represent the sedimentation cycles detected by each ratio. (B) Signals of depositional cycles stand out above the 95\% confidence interval (CI) in the power spectra. Arrows represent the most dominant depositional signal. (D) Fast Fourier Transform processing also demonstrates the frequency of the strongest depositional signal (light-colored bands). 


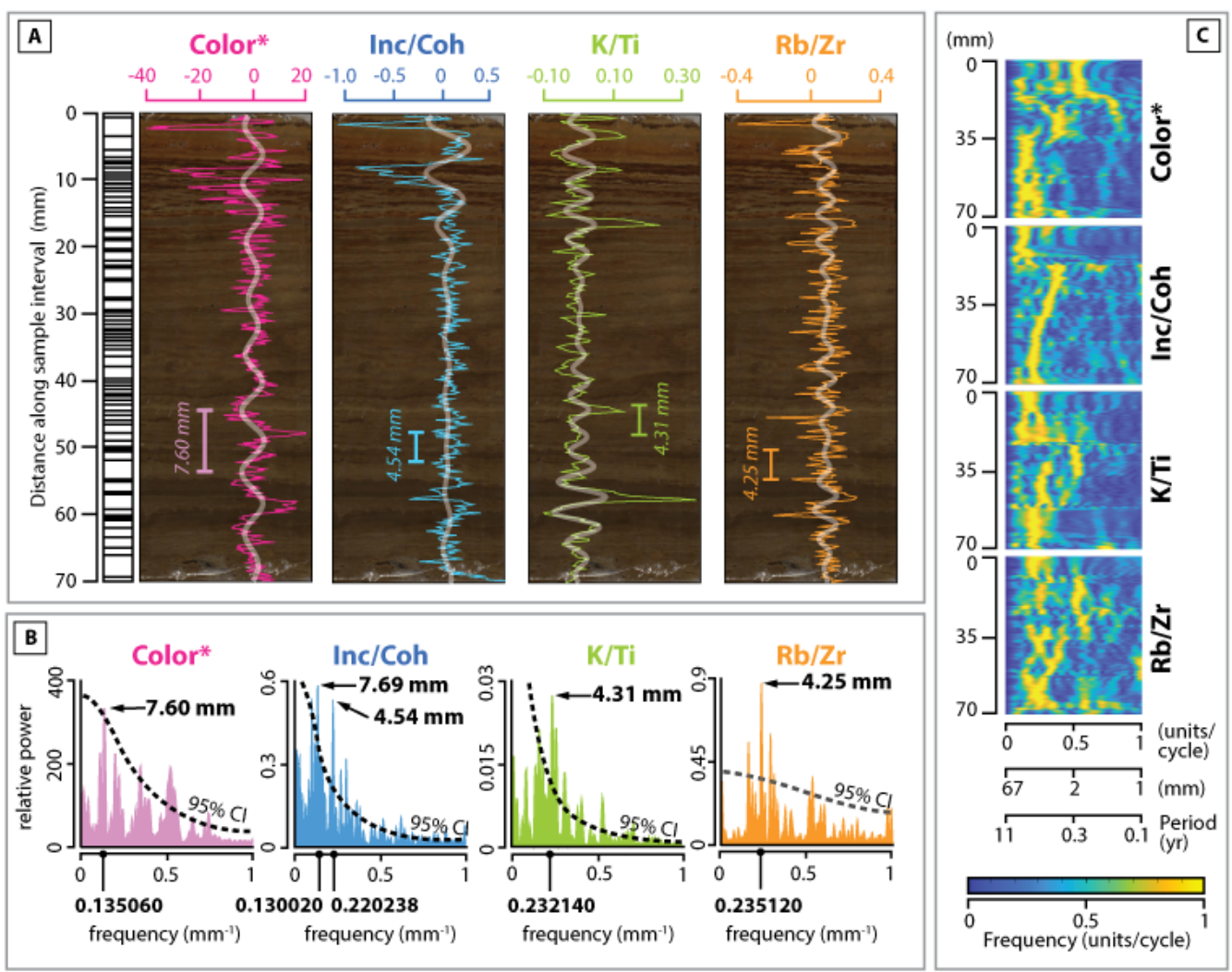

Figure S5. Spectral analysis of the Unit 5A. (A) Frequency analysis Color*, Inc/Coh, K/Ti and $\mathrm{Zr} / \mathrm{Rb}$ ratios show depositional cycles at every 4.25-7.69 $\mathrm{mm}$ in Unit 5A. The cyclicity of the *Color data $(7.60 \mathrm{~mm})$ large deviates from the other indices, probably because it is less sensitive to sediment cycles in this oxidized unit with low organic carbon content. Consequently, for the age model, the average between three depositional cycle values based on Inc/Coh, K/Ti and $\mathrm{Zr} / \mathrm{Rb}$ was used to decrease the scatter (4.25-4.54 mm). (B) Signals of depositional cycles stand out above the $95 \%$ confidence interval (CI) in the power spectra. Arrows represent the most dominant depositional signal. (D) Fast Fourier Transform processing also demonstrates the frequency of the strongest depositional signal (light-colored bands). 


\section{REFERENCES CITED}

Anderson, R. Y., \& Dean, W. E. (1988). Lacustrine varve formation through time. Palaeogeography, Palaeoclimatology, Palaeoecology. https://doi.org/10.1016/00310182(88)90055-7

Barr, S. M., Van Rooyen, D., Miller, B. V., White, C. E., \& Johnson, S. C. (2019). Detrital zircon signatures in Precambrian and Paleozoic sedimentary units in southern New Brunswick - more pieces of the puzzle. Atlantic Geology, 55, 275-322. https://doi.org/10.4138/atlgeol.2019.010

Condon, D. J., Schoene, B., McLean, N. M., Bowring, S. A., \& Parrish, R. R. (2015). Metrology and traceability of $\mathrm{U}-\mathrm{Pb}$ isotope dilution geochronology (EARTHTIME Tracer Calibration Part I). Geochimica et Cosmochimica Acta, 164, 464-480. https://doi.org/10.1016/j.gca.2015.05.026

Croudace, I. W., Rindby, A., \& Rothwell, R. G. (2006). ITRAX: Description and evaluation of a new multi-function X-ray core scanner. Geological Society Special Publication. https://doi.org/10.1144/GSL.SP.2006.267.01.04

Gehrels, G. E., Valencia, V. A., \& Ruiz, J. (2008). Enhanced precision, accuracy, efficiency, and spatial resolution of $\mathrm{U}-\mathrm{Pb}$ ages by laser ablation-multicollector-inductively coupled plasmamass spectrometry. Geochemistry, Geophysics, Geosystems, 9(3), 1-13. https://doi.org/10.1029/2007GC001805

Li, M., Hinnov, L., \& Kump, L. (2019). Acycle: Time-series analysis software for paleoclimate research and education. Computers \& Geosciences, 127, 12-22. https://doi.org/10.1016/j.cageo.2019.02.011

Ludwig, K. R. (2003). User's manual for Isoplot 3.00, a geochronological toolkit for Microsoft Excel. Berkeley Geochronology Center special publication no.4. Components.

Mann, M. E., \& Lees, J. M. (1996). Robust estimation of background noise and signal detection in climatic time series. Climatic Change, 33(3), 409-445. https://doi.org/10.1007/BF00142586

Mattinson, J. M. (2005). Zircon U-Pb chemical abrasion (“CA-TIMS”) method: Combined annealing and multi-step partial dissolution analysis for improved precision and accuracy of zircon ages. Chemical Geology, 220(1-2), 47-66. https://doi.org/10.1016/j.chemgeo.2005.03.011

Miller, B. V., Barr, S. M., Tesfai, F., \& White, C. E. (2018). Tonian Fe-Ti-P ferronorite and alkali anorthosite in the northern Appalachian orogen, southern New Brunswick, Canada: Amazonian basement in Ganderia? Precambrian Research. https://doi.org/10.1016/j.precamres.2018.08.006

Muller, R. A., \& MacDonald, G. J. (2000). Ice Ages and Astronomical Causes: Data, Spectral Analysis, and Mechanisms. Berlin: Springer-Verlag Berlin Heidelberg.

Park, A. F., Treat, R. L., Barr, S. M., White, C. E., Miller, B. V., Reynolds, P. H., \& Hamilton, M. A. (2014). Structural setting and age of the partridge island block, southern New Brunswick, Canada: A link to the Cobequid highlands of northern mainland Nova Scotia. 
Canadian Journal of Earth Sciences. https://doi.org/10.1139/cjes-2013-0120

Schmitz, M. D., \& Schoene, B. (2007). Derivation of isotope ratios, errors, and error correlations for U-Pb geochronology using $205 \mathrm{~Pb}-235 \mathrm{U}-(233 \mathrm{U})$-spiked isotope dilution thermal ionization mass spectrometric data. Geochemistry, Geophysics, Geosystems, 8(8), n/a-n/a. https://doi.org/10.1029/2006GC001492

Smith, J. J., Turner, E., Möller, A., Joeckel, R. M., \& Otto, R. E. (2018). First U-Pb zircon ages for late Miocene ashfall Konservat-Lagerstätte and Grove Lake ashes from eastern Great Plains, USA. PLoS ONE. https://doi.org/10.1371/journal.pone.0207103

Trauth, M. H. (2015). Time-Series Analysis. In MATLAB ${ }^{\circledR}$ Recipes for Earth Sciences (pp. 151213). Berlin, Heidelberg: Springer Berlin Heidelberg. https://doi.org/10.1007/978-3-66246244-7_5

Wiedenbeck, M., Allé, P., Corfu, F., Griffin, W. L., Meier, M., Oberli, F., et al. (1995). Three Natural Zircon Standards For U-Th-Pb, Lu-Hf, Trace Element and REE Analyses.

Geostandards and Geoanalytical Research, 19(1), 1-23. https://doi.org/10.1111/j.1751908X.1995.tb00147.x

Yancey, T. E., Heizler, M. T., Miller, B. V., \& Guillemette, R. N. (2018). Eocene-Oligocene chronostratigraphy of ignimbrite flareup volcanic ash beds on the Gulf of Mexico coastal plains. Geosphere, 14(3), 1232-1252. https://doi.org/10.1130/GES01621.1

Zolitschka, B., Francus, P., Ojala, A. E. K., \& Schimmelmann, A. (2015). Varves in lake sediments - a review. Quaternary Science Reviews, 117, 1-41.

https://doi.org/10.1016/j.quascirev.2015.03.019 